\title{
Effect of the essential oil of Rosmarinus officinalis (L.) on rooster sperm motility during $4^{\circ} \mathrm{C}$ short-term storage
}

\author{
L. Touazi ${ }^{1,2}$, B. Aberkane ${ }^{3}$, Y. Bellik ${ }^{4}$, N. Moula ${ }^{5}$ and M. Iguer-Ouada ${ }^{2}$
}

1. Ecole Nationale Supérieure Vétérinaire, Rue Issad Abbes, Oued Smar, Algiers, Algeria; 2. Associated Laboratory in Marine and Aquaculture Ecosystems, Faculty of Nature and Life Sciences, University of Bejaia. Algeria; 3. Department of Biology, Faculty of Nature and Life Sciences and Earth Sciences. University of Bouira, Algeria; 4. Department of Biology, Faculty of Nature and Life Sciences, University of El Bachir el Ibrahimi, Bordj Bou Arreridj, 34000, Algeria; 5. Department of Animal Productions, University of Liege, Faculty of Veterinary Medicine, 4000 Liege, Belgium.

Corresponding author: L. Touazi, e-mail: touazil@gmail.com

Co-authors: BA: aberkaneboubekeur@gmail.com, YB: byouba@gmail.com, NM: nassim.moula@ulg.ac.be, MI: imokrane@gmail.com

Received: 22-12-2017, Accepted: 06-04-2018, Published online: 09-05-2018

doi: 10.14202/vetworld.2018.590-597 How to cite this article: Touazi L, Aberkane B, Bellik Y, Moula N, Iguer-Ouada M (2018) Effect of the essential oil of Rosmarinus officinalis (L.) on rooster sperm motility during $4^{\circ} \mathrm{C}$ short-term storage, Veterinary World, 11(5): 590-597.

\begin{abstract}
Aim: This study aimed to investigate the protective effect of Rosmarinus officinalis (L.) essential oil on rooster sperm motility during $4^{\circ} \mathrm{C}$ short-term storage.

Materials and Methods: $R$. officinalis essential oil was analyzed using gas chromatography coupled to mass spectrometry to identify the active components. 10 of 45-week-old Hubbard commercial broilers were subjected to biweekly semen collections during 3 weeks. At each collection, sperm was pooled and divided into four aliquots and then diluted with Tris extender supplemented with 870,87 , or $8.7 \mu \mathrm{g} / \mathrm{ml}$ of $R$. officinalis essential oil, identified as treatments R, R5, and R10, respectively. Tris-based extender without any supplementation was considered as a control group. Diluted sperm was then stored at $4^{\circ} \mathrm{C}$ in the refrigerator and analyzed at $0,6,24$, and $48 \mathrm{~h}$ using a computer-assisted sperm analyzer. Different semen parameters were measured including total motility, progressive motility, gametes velocities (straight line velocity [VSL], curvilinear velocity [VCL], and average path velocity [VAP]), amplitude of the lateral head displacement [ALH], and beatcross frequency $[\mathrm{BCF}]$.

Results: The phytochemical analysis of $R$. officinalis essential oil revealed the presence of 25 active components including seven major molecules: Camphor (18.88\%), camphene (5.17\%), 1,8-cineole (7.85\%), $\beta$-thujene (13.66\%), $\alpha$-thujene (4.87\%), chrysanthenone $(12.05 \%)$, and $\beta$-cubenene $(7.97 \%)$. The results showed a beneficial effect of $R$. officinalis essential oil on sperm cells motility, particularly when using the lowest concentrations, 8.7 and $87 \mu \mathrm{g} / \mathrm{ml}$. Progressive motility and gametes velocities (VCL, VSL, and VAP), materializing the quality of gametes motility, showed highly statistically significant values $(\mathrm{p}<0.01)$ in 8.7 and $87 \mu \mathrm{g} / \mathrm{ml}$ treatments, especially from $6 \mathrm{~h}$ of storage at $4^{\circ} \mathrm{C}$. Conversely, the highest concentration $(870 \mu \mathrm{g} / \mathrm{ml})$ showed harmful effects with a total spermicidal activity after $24 \mathrm{~h}$ of storage.
\end{abstract}

Conclusion: The current results revealed the positive impact of $R$. officinalis essential oil on rooster sperm at $4^{\circ} \mathrm{C}$ short-term storage probably through fighting against oxidative stress and cold shock damages.

Keywords: antioxidant, avian semen, liquid storage, rosemary essential oil.

\section{Introduction}

The recent years witnessed, in poultry, a growing interest in wide ranges of natural products and plant extracts, especially about their positive effects on reproduction and fertility outputs [1-3]. Essential oils, when used particularly in vivo as dietary supplementation, showed a remarkable potency in protecting and improving sperm parameters of several animal species [4-7]. However, when used in vitro, in humans as well in other animal species, essential evidenced spermicidal effects with

Copyright: Touazi, et al. Open Access. This article is distributed under the terms of the Creative Commons Attribution 4.0 International License (http://creativecommons.org/licenses/by/4.0/), which permits unrestricted use, distribution, and reproduction in any medium, provided you give appropriate credit to the origina author(s) and the source, provide a link to the Creative Commons license, and indicate if changes were made. The Creative Commons Public Domain Dedication waiver (http://creativecommons.org/ publicdomain/zero/1.0/) applies to the data made available in this article, unless otherwise stated. impacts on gametes motility and plasma membrane integrity [8-12].

Rosmarinus officinalis is known as a rich source of polyphenols and volatile oils including molecules such as carnosic, rosmarinic acids, and camphor [13-16]. These compounds display diverse biological activities including antioxidant, anti-inflammatory, and anticarcinogenic properties. In aged roosters, Borghei-Rad et al. [17] reported that dietary supplementation with rosemary leaves powder improved significantly semen quality, fertility, and hatchability through fighting oxidative stress damages. Similarly, dietary supplementation using other antioxidants, including Vitamin E, selenium, Vitamin C, and enzymatic antioxidant systems, improved significantly animal health and sperm quality [18-21].

Sperm cells are known to be more vulnerable to reactive oxygen species (ROS), generated during 
oxidative stress, than somatic cells due to gametes cell structure and their limited contents of antioxidants. In this respect, the phospholipidic fraction of spermatozoa cell membranes [22] is the first target of ROS with negative effects on membrane fluidity and the subsequent impairment of motility, acrosome reaction, and sperm-egg interaction [23,24]. Accordingly, high membrane concentration in PUFA makes sperm cells more susceptible to lipid peroxidation, especially, during the different stages of in vitro storage at low temperatures compromising, thus fertility outputs [24,25].

In fact, in rooster, artificial insemination (AI) is routinely carried out after short-term storage at $4^{\circ} \mathrm{C}$; however, reports evidenced that fertilizing capacity of freshly collected semen is dramatically lost after half an hour of collection [22]. Therefore, development of optimal semen extenders, including different active compounds, was considered worldwide by different research groups to protect sperm cells against motility damages. The adopted strategies consisted essentially of protecting cell membrane against cold shock and oxidative stress [26,27].

In this respect, numerous studies, using rosemary leaves extract, containing rich fractions of polyphenols, have reported positive effects on frozen semen in several species including boar [28], dog [29], and ram [30]. However, no protective effect was reported when using $R$. officinalis essential oil, and recently, Elmi et al. [31] observed similar motilities when comparing the control to sperm treated in vitro with $0.2 \mathrm{mg} / \mathrm{ml}$ of $R$. officinalis essential oil. Overall, all the reported data independently on the considered plant showed an obvious spermicidal activity.

Thus, to the best of our knowledge, no previous records reported the usefulness of essential oils as protective factors during semen preservation at low temperatures. This study aimed to investigate the interest of $R$. officinalis essential oil in the preservation of rooster sperm motility during $4{ }^{\circ} \mathrm{C}$ short-term storage.

\section{Materials and Methods \\ Ethical approval}

The experiment was carried out in accordance with the guidelines laid down by the Directive 2010/63/EU of the European Parliament for Animal Ethics Committee for the use of poultry birds.

\section{Plant material}

Aerial part (stems and leaves) of $R$. officinalis was harvested during April 2015, in the region of El-Euchre, in the Department of Bordj Bou Arreridj, located in Northeastern Algeria. The harvested plants were dried in the shade for 10 days before extraction.

Extraction of the essential oil was carried out by hydrodistillation process using a Clevenger's type apparatus (Clevenger, 1928). Distillations were carried out by boiling aerial plant parts for $3 \mathrm{~h}$, and the essential oil was kept in air-tight sealed vials and stored at $4^{\circ} \mathrm{C}$ until further use.

\section{Phytochemical identification}

The identification of the active compounds of the $R$. officinalis essential oil was carried out by Agilent 2890 HP-type gas chromatography coupled to mass spectrometry (Model 6890) (GC/MS), equipped with a fused silica HP-5MS capillary column (Length: $30 \mathrm{~m}$, internal diameter: $0.25 \mathrm{~mm}$, and film thickness $0.25 \mu \mathrm{m})$. The temperature of the injector was maintained at $250^{\circ} \mathrm{C}$. The carrier gas was helium $(0.5 \mathrm{ml} / \mathrm{min})$ with an injection volume of $0.2 \mu \mathrm{l}$, and the division ratio was adjusted to $1: 20$. The oven temperature was programmed from $60(8 \mathrm{~min})$ to $280^{\circ} \mathrm{C}$ at $2^{\circ} \mathrm{C} / \mathrm{min}$ and then held isothermally at $280^{\circ} \mathrm{C}$ for $10 \mathrm{~min}$. Analysis mode: Digitized, interface temperature: $280^{\circ} \mathrm{C}$, ionization type: Electronic, filament strength: $70 \mathrm{eV}$, mass analyzer type: Quadrupole, source temperature: $230^{\circ} \mathrm{C}$, and empty: $65 \mathrm{~m}$ torr.

\section{Animals}

All experiments were conducted in accordance with the legislation governing the ethical treatment of animals. 10 of 45-week-old Hubbard commercial broiler reproductive cocks were used during the experiment. The animals were housed in conventional individual cages under $14 \mathrm{~h}$ of daily illumination and fed with a standard commercial food at the rate of $155 \mathrm{~g} /$ day/animal.

\section{Sperm collection}

The roosters were subjected to biweekly semen collections during 3 weeks by dorso-abdominal massage as described by Burros and Quinn [32] and individual ejaculates were gently mixed and pooled. To minimize animal stress, the collection was carried out by the same operator and under the same conditions. Necessary precautions were taken during collection to avoid contamination by cloaca fluids. Sperm concentration was calculated using a computer-assisted sperm analyzer (CASA) (Sperm class analyzer, SCA Microptic, S.L., Version 3.2.0, Barcelona, Spain).

\section{Sperm treatment}

The pooled sperm was diluted at $1 / 2$ ratio at room temperature $\left(18-22^{\circ} \mathrm{C}\right)$ in Tris extender $(3.028 \mathrm{~g}$ of hydroxymethylaminomethane, $1.25 \mathrm{~g}$ of fructose, $1.7 \mathrm{~g}$ of citric acid, $800 \mathrm{Ul} / \mathrm{ml}$ of penicillin $\mathrm{G}$ sodium, and $1 \mathrm{mg} / \mathrm{ml}$ of streptomycin sulfate in $100 \mathrm{ml}$ of distilled water) and then split into four equal aliquots. Each aliquot was diluted with Tris extender supplemented with 870,87 , or $8.7 \mu \mathrm{g} / \mathrm{ml}$ of $R$. officinalis essential oil, identified as treatments R, R5, and R10, respectively (26). Tris-based extender without any supplementation was considered as a control group. All samples were then stored at $4^{\circ} \mathrm{C}$ and analyzed at $0,6,24$, and $48 \mathrm{~h}$. The experimentation was repeated 6 times $(n=6)$.

\section{Sperm motility analysis}

Various sperm motility parameters were analyzed using a CASA (Sperm class analyzer, SCA Microptic, S.L., Version 3.2.0, Barcelona, Spain). The measured parameters were: Percentage of motile 
spermatozoa (Mob $\mathrm{T} \%$ ), percentage of progressive spermatozoa (Prog T \%), curvilinear velocity (VCL $\mu \mathrm{m} / \mathrm{s}$ ), straight line velocity (VSL $\mu \mathrm{m} / \mathrm{s}$ ), average path velocity (VAP $\mu \mathrm{m} / \mathrm{s}$ ), amplitude of the lateral head displacement (ALH $\mu \mathrm{m})$, and frequency to which the sperm head crosses the mean trajectory (beat-cross frequency $[\mathrm{BCF}] / \mathrm{Hertz})$.

\section{Statistical analysis}

The SAS software (SAS Institute, 2001) was used for all statistical analyses. The data were checked for normal distribution with a Shapiro-Wilk test. Treatment and time effect on each motility parameters (MobT, ProgT, VCL, VSL, VAP, ALH, and BCF) were assessed by the following general linear model:

$\mathrm{Y}_{\mathrm{ijk}}=\mu+\mathrm{A}_{\mathrm{i}}+\mathrm{B}_{\mathrm{j}}+(\mathrm{AB})_{\mathrm{ij}}+\mathrm{e}_{\mathrm{ijk}}$

$\mathrm{Y}=$ The studied motility parameters measured on the sperm;

$\mu=$ Mean;

$\mathrm{A}_{\mathrm{i}}=$ Fixed effect of the medium ( $\mathrm{i}=1-4: \mathrm{R}, \mathrm{R}$, R10, and Tris); $48 \mathrm{~h})$;

$B_{j}=$ Fixed effect of time $(j=1-4: 0,6,24$, and

$(\mathrm{AB})_{\mathrm{ij}}=$ Interaction between time and medium;

$\mathrm{e}_{\mathrm{ijk}}=$ The residual effect.

Least-squares means and standard errors (SE) were calculated for motility parameters measurements.

Differences were considered statistically significant at $\mathrm{p}<0.05$.

\section{Results}

The chemical composition of $R$. officinalis essential oil and the retention index as well as the percentages of the various compounds are listed in Table-1. 25 compounds were identified in the essential oil without fractionation. The major constituents were camphor (18.88\%), camphene (5.17\%), 1,8-cineole $(7.85 \%)$, $\beta$-thujene (13;66\%), $\alpha$-thujene $(4.87 \%)$, chrysanthenone (12.05\%), and $\beta$-cubenene (7.97\%).

\section{Effect of storage time and sperm treatment on sperm mobility parameters}

The effects of time, sperm treatment, and their interactions sperm motility are shown in Table-2. The interaction affected all the variables significantly $(\mathrm{p}<0.001)$. The total and progressive motility declined rapidly at $870 \mu \mathrm{g} / \mathrm{ml}$ corresponding to the highest concentration of $R$. officinalis essential, especially after $6 \mathrm{~h}$ of storage. Similar observations are noted for the kinematics parameters (VSL, VCL, VAP, ALH, and $\mathrm{BCF})$.

\section{Percentage of total motility}

Figure-1 shows the effects of different treatments on total motility during the study period. Total motility represents the percentage of total moving spermatozoa regardless of the quality of the motility. When compared to the control group (Tris), statistically significant impact was observed in the different treatments $(\mathrm{p}<0.001)$. At $\mathrm{T} 0$, no significant difference was observed between $87 \mu \mathrm{g} / \mathrm{ml}$ (R5, 89.84 \pm 3.64 ) and $8.7 \mu \mathrm{g} / \mathrm{ml}(\mathrm{R} 10,98.12 \pm 0.16)$ treatments and the control group (Tris, $92.03 \pm 1.32$ ). The highest concentration of $R$. officinalis essential oil $(\mathrm{R}, 870 \mu \mathrm{g} / \mathrm{ml})$ showed the lowest motility percentage at 0 and $6 \mathrm{~h}$ and a total spermicidal effect at $24 \mathrm{~h}$. After $48 \mathrm{~h}$ of chilling storage, 87 and $8.7 \mu \mathrm{g} / \mathrm{ml}$ concentrations expressed the highest motility with $71.4 \pm 2.05 \%$ and $74 \pm 6.49 \%$, respectively.

\section{Percentage of progressive motility}

Progressive motility is a qualitative parameter representing gametes with forwarding motility (Figure-2). As for total motility (Figure-1), the lowest progressive gametes were observed in $870 \mu \mathrm{g} / \mathrm{ml}$ treatment corresponding to the highest essential oil concentration. From $6 \mathrm{~h}$ of storage, progressive motility was significantly preserved in 87 and $8.7 \mu \mathrm{g} / \mathrm{ml}$ treatments. After $24 \mathrm{~h}$ of storage, 87 and $8.7 \mu \mathrm{g} / \mathrm{ml}$ treatments showed $43.25 \pm 2.43$ and $63.08 \pm 5.33 \%$ of progressive gametes compared to $26.86 \pm 2.36 \%$ of the control group $(\mathrm{p}<0.05)$.

\section{Cinematic parameters (VCL, VSL, VAP, ALH, and BCF)}

Cinematic parameters including velocities (VCL, VSL, and VAP), ALH, and BCF are represented in Figure-3. The velocity of individual sperm was ranged between 0 (immotile sperm) and $100 \mu \mathrm{m} / \mathrm{s}$. After $6 \mathrm{~h}$ of storage, highly significant differences were observed for VCL $(p<0.01)$, VSL $(p<0.01)$, and $\operatorname{VAP}(p<0.01)$ in $8.7 \mu \mathrm{g} / \mathrm{ml}$ treatment with $57.07 \pm 0.62,14.23 \pm 0.26$, and $29.31 \pm 0.34 \mu \mathrm{m} / \mathrm{s}$, respectively. This positive impact was maintained at 24 and $48 \mathrm{~h}$. Similarly, ALH and

Table-1: Main compounds of the $R$. officinalis essential oil identified by GC/MS.

\begin{tabular}{lcc}
\hline Compound & RI & \% \\
\hline$\alpha$-Pinene & 8.881 & 1.409 \\
Camphene & 9.734 & 5.171 \\
Verbenene & 10.028 & 0.586 \\
Sabinene & 11.185 & 1.374 \\
$\beta$-Pinene & 11.329 & 0.254 \\
trans $\beta$-Ocimène & 12.317 & 0.231 \\
$\alpha$-Terpinene & 13.937 & 0.54 \\
1,8-Cineole & 14.978 & 7.850 \\
$\gamma$-Terpinene & 16.852 & 0.667 \\
$\beta$-Thujene & 20.404 & 13.662 \\
$\alpha$-Thujene & 21.113 & 4.875 \\
Chrysanthenone & 21.797 & 11.548 \\
Camphor & 23.176 & 18.88 \\
Carveol & 23.267 & 0.31 \\
Pinocarvone & 24.221 & 0.618 \\
$\alpha$-Phellandrene & 24.939 & 0.556 \\
Terpineol & 25.460 & 0.904 \\
Chrysanthenyl acetate & 31.161 & 1.479 \\
$\alpha$-Copaene & 38.554 & 0.517 \\
cis-Jasmone & 40.357 & 0.491 \\
$\beta$-Cubebene & 45.311 & 7.976 \\
$\gamma$-Elemene & 46.145 & 1.719 \\
$\delta$-Cadinene & 47.798 & 0.625 \\
Spathulenol & 51.090 & 0.158 \\
1,3 -Nonadiene & 71.438 & 0.874 \\
\hline$R$ - & &
\end{tabular}

R. officinalis=Rosmarinus officinalis, GS-MS=Gas chromatography-mass spectrometer 
Available at www.veterinaryworld.org/Vol.11/May-2018/4.pdf

\begin{tabular}{|c|c|c|c|c|c|c|c|c|c|c|}
\hline \multirow[t]{2}{*}{ Motility parameters } & \multirow[t]{2}{*}{ TRT } & \multicolumn{4}{|c|}{ Storage time (ST) } & \multirow[t]{2}{*}{ SEM } & \multicolumn{3}{|c|}{ p value } & \multirow[t]{2}{*}{$\mathbf{R}^{2}$} \\
\hline & & $\mathbf{0}$ & 6 & 24 & 48 & & TRT & ST & TRT*ST & \\
\hline \multirow[t]{4}{*}{ Mob T } & $\mathrm{R}$ & $71.24^{a}$ & $14.68^{b}$ & - & - & 2.83 & $* * *$ & $* * *$ & $* * *$ & 0.97 \\
\hline & R5 & $89.84^{a}$ & $92.44^{\mathrm{a}}$ & $88.96^{a}$ & $71.43^{\mathrm{b}}$ & 2.83 & & & & \\
\hline & R10 & $98.12^{\mathrm{a}}$ & $91.96^{\mathrm{a}}$ & $92.80^{\mathrm{a}}$ & $74.00^{\mathrm{b}}$ & 2.83 & & & & \\
\hline & Tris & $92.03^{a}$ & $87.03^{a b}$ & $83.93^{b}$ & $54.04^{c}$ & 2.83 & & & & \\
\hline \multirow[t]{4}{*}{ Prog T } & $\mathrm{R}$ & $30.87^{a}$ & $1.62^{\mathrm{b}}$ & - & - & 4.72 & $* * *$ & $* * *$ & $* * *$ & 0.90 \\
\hline & R5 & $50.82^{a}$ & $68.32^{\mathrm{b}}$ & $43.25^{a}$ & $27.31^{\mathrm{c}}$ & 4.72 & & & & \\
\hline & R10 & $70.30^{\mathrm{a}}$ & $56.43^{b}$ & $63.08^{\mathrm{ab}}$ & $36.48^{c}$ & 4.72 & & & & \\
\hline & Tris & $64.94^{a}$ & $39.87^{b}$ & $26.86^{\mathrm{bc}}$ & $15.18^{\mathrm{c}}$ & 4.72 & & & & \\
\hline \multirow[t]{4}{*}{ VSL } & $\mathrm{R}$ & $9.24^{a}$ & $4.27^{b}$ & - & - & 0.39 & $* * *$ & $* * *$ & $* * *$ & 0.06 \\
\hline & R5 & $12.02^{\mathrm{a}}$ & $9.90^{\mathrm{b}}$ & $7.74^{c}$ & $10.96^{d}$ & 0.18 & & & & \\
\hline & R10 & $11.79^{\mathrm{a}}$ & $14.23^{b}$ & $10.32^{c}$ & $11.71^{\mathrm{a}}$ & 0.23 & & & & \\
\hline & Tris & $13.21^{\mathrm{a}}$ & $8.78^{\mathrm{b}}$ & $4.22^{c}$ & $8.55^{b}$ & 0.24 & & & & \\
\hline \multirow[t]{4}{*}{ VCL } & $\mathrm{R}$ & $32.48^{a}$ & $18.17^{b}$ & - & - & 0.92 & $* * *$ & $* * *$ & $* * *$ & 0.11 \\
\hline & R5 & $40.47^{a}$ & $34.60^{\mathrm{b}}$ & $28.69^{c}$ & $39.05^{d}$ & 0.44 & & & & \\
\hline & R10 & $43.57^{a}$ & $57.07^{b}$ & $42.46^{a}$ & $38.05^{c}$ & 0.56 & & & & \\
\hline & Tris & $45.90^{a}$ & $28.46^{b}$ & $28.53^{b}$ & $32.56^{c}$ & 0.62 & & & & \\
\hline \multirow[t]{4}{*}{ VAP } & $\mathrm{R}$ & $17.35^{\mathrm{a}}$ & $8.47^{b}$ & - & - & 0.47 & $* * *$ & $* * *$ & $* * *$ & 0.09 \\
\hline & R5 & $22.56^{a}$ & $20.35^{b}$ & $17.52^{c}$ & $20.24^{b}$ & 0.26 & & & & \\
\hline & R10 & $23.11^{\mathrm{a}}$ & $29.31^{\mathrm{b}}$ & $22.04^{c}$ & $20.24^{d}$ & 0.30 & & & & \\
\hline & Tris & $24.20^{a}$ & $18.42^{b}$ & $11.00^{c}$ & $17.55^{d}$ & 0.35 & & & & \\
\hline \multirow[t]{4}{*}{ ALH } & $\mathrm{R}$ & $2.12^{\mathrm{a}}$ & $1.76^{\mathrm{b}}$ & - & - & 0.05 & $* * *$ & $* * *$ & $* * *$ & 0.15 \\
\hline & R5 & $2.53^{a}$ & $2.23^{b}$ & $1.48^{\mathrm{c}}$ & $2.95^{d}$ & 0.02 & & & & \\
\hline & R10 & $3.03^{a}$ & $2.33^{b}$ & $2.55^{c}$ & $2.89^{d}$ & 0.03 & & & & \\
\hline & Tris & $2.74^{a}$ & $1.87^{\mathrm{b}}$ & $1.41^{c}$ & $2.62^{\mathrm{d}}$ & 0.03 & & & & \\
\hline \multirow[t]{4}{*}{$\mathrm{BCF}$} & $\mathrm{R}$ & $2.98^{\mathrm{a}}$ & $1.18^{\mathrm{b}}$ & - & - & 0.09 & $* * *$ & $* * *$ & $* * *$ & 0.08 \\
\hline & R5 & $3.62^{\mathrm{a}}$ & $3.44^{\mathrm{b}}$ & $3.11^{\mathrm{c}}$ & $3.41^{\mathrm{b}}$ & 0.05 & & & & \\
\hline & R10 & $3.77^{a}$ & $4.94^{b}$ & $3.25^{c}$ & $3.59^{d}$ & 0.05 & & & & \\
\hline & Tris & $4.41^{\mathrm{a}}$ & $3.23^{\mathrm{b}}$ & $1.62^{\mathrm{c}}$ & $3.05^{d}$ & 0.06 & & & & \\
\hline
\end{tabular}

Means followed by the same letter $(a, b, c)$ in the same line are not statistically significant different $(p>0.05)$.

$* * * \mathrm{p}<0.001$; SEM=Standard error of mean, $\mathrm{R}^{2}=$ Coefficient of determination, $\mathrm{VSL}=$ Straight line velocity, $\mathrm{VCL}=\mathrm{Straight}$ line velocity, $\mathrm{VAP}=$ Average path velocity, $\mathrm{ALH}=\mathrm{Amplitude}$ of the lateral head displacement, $\mathrm{BCF}=\mathrm{Beat}-\mathrm{cross}$ frequency

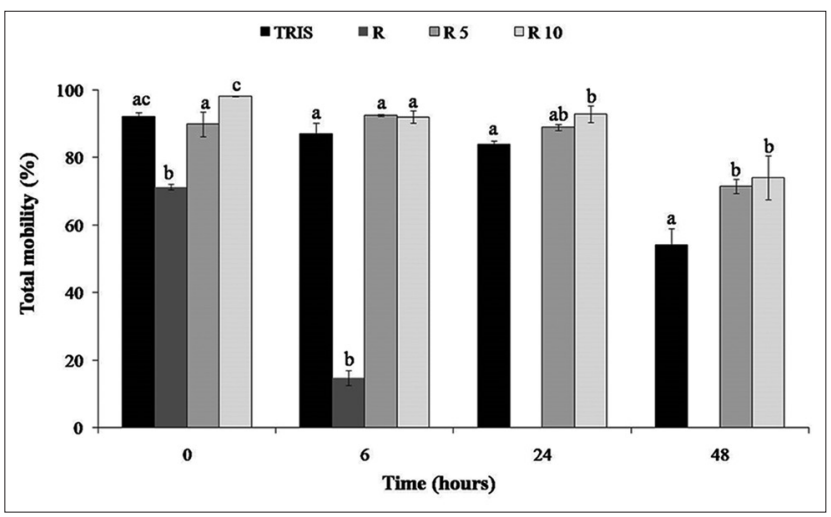

Figure-1: Total motility percentage of rooster spermatozoa in control (Tris) and Rosmarinus officinalis essential oil treatments R $(870 \mu \mathrm{g} / \mathrm{ml})$, R5 $(87 \mu \mathrm{g} / \mathrm{ml})$, and R10 $(8.7 \mu \mathrm{g} / \mathrm{ml})$ at $0,6,24$, and $48 \mathrm{~h}$ of $4^{\circ} \mathrm{C}$ storage. Different letters indicate statistically significant difference $(p<0.05)$. Values are represented as mean \pm standard error of the mean.

BCF showed the highest values in 87 and $8.7 \mu \mathrm{g} / \mathrm{ml}$ treatments.

\section{Discussion}

Nowadays, rosemary is widely used for its antioxidant activity [33-38], antimicrobial properties [38-41], and bio-preservative in the food industry [42-44]. Recently, in poultry, Borghei-Radand et al. [17]

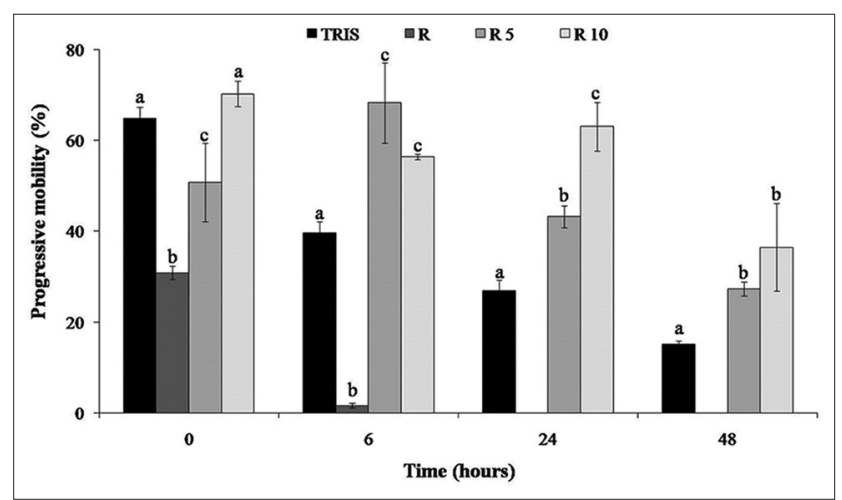

Figure-2: Progressive motility percentage of rooster spermatozoa in control (Tris) and Rosmarinus officinalis essential oil treatments R $(870 \mu \mathrm{g} / \mathrm{ml}), \mathrm{R} 5(87 \mu \mathrm{g} / \mathrm{ml})$, and R10 $(8.7 \mu \mathrm{g} / \mathrm{ml})$ at $0,6,24$, and $48 \mathrm{~h}$ of $4^{\circ} \mathrm{C}$ storage. Different letters indicate statistically significant difference $(p<0.05)$. Values are represented as mean \pm standard error of the mean.

reported positive effects of diet supplementation using $R$. officinalis leaves on sperm motility and fertility in aging roosters. However, very few relevant data are present regarding the protective effect of $R$. officinalis essential oil on avian spermatozoa, particularly when used in vitro.

In this study, the chemical composition of R. officinalis essential oil and the effects on rooster 


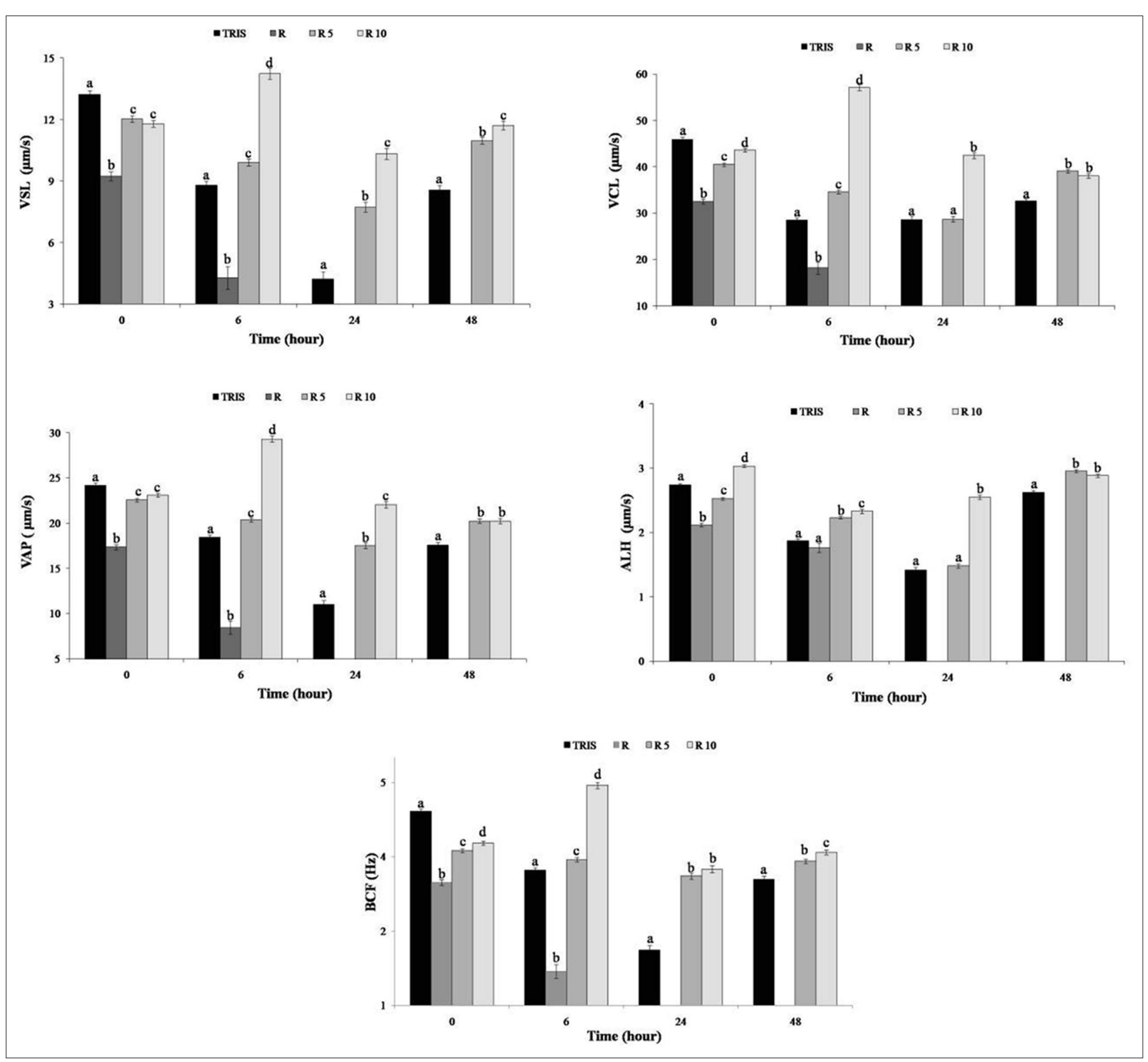

Figure-3: Curvilinear velocity (VCL), straight line velocity (VSL), average path velocity (VAP), amplitude of lateral movement of the head (ALH), and the beat-cross frequency (BCF/Hertz) of rooster spermatozoa in the control (Tris) and Rosmarinus officinalis essential oil treatments $\mathrm{R}(870 \mu \mathrm{g} / \mathrm{ml})$, R5 $(87 \mu \mathrm{g} / \mathrm{ml})$, and R10 $(8.7 \mu \mathrm{g} / \mathrm{ml})$ at $0,6,24$, and $48 \mathrm{~h}$ of $4^{\circ} \mathrm{C}$ storage. Different letters indicate statistically significant difference $(p<0.05)$. Values are represented as mean \pm standard error of the mean.

sperm motility during $4^{\circ} \mathrm{C}$ short-term were studied. Phytochemical screening of $R$. officinalis essential oil (using the GC-MS analysis) allowed the identification of 25 active compounds. According to the results, the major constituents were camphor (18.88\%), 1,8-cineole (7.85\%), $\beta$-thujone $(13 ; 66 \%)$, chrysanthenone $(12.05 \%)$, and $\beta$-cubenene (7.97\%). Similar results were reported by Zermane et al. [45] when investigating the chemical analysis of Algerian essential oil under optimal conditions. The analyzed essential oil presented some differences when compared to Moroccan $R$. officinalis essential oil. The latter showed high proportions of pinene (37-40\%), cineole (58.7-63.7\%), and camphor (41.7-53.8\%) and $R$. officinalis essential oil from Tunisia is rich in cineole and contained usual monoterpenes [46,47]. Previous studies revealed that $R$. officinalis essential oil composition might be influenced by various factors such as the genotype of the plant, soil type, bioclimatic conditions, or the extraction method [47-49].

In the present study, the beneficial and potentially harmful effects of different concentrations of $R$. officinalis essential oil on rooster semen stored at $4^{\circ} \mathrm{C}$ for $48 \mathrm{~h}$ were investigated. The results demonstrated that semen quality (revealed through progressive motility and gametes velocities) was significantly preserved, especially with the lowest concentrations of the essential oil $(87 \mu \mathrm{g} / \mathrm{ml}$ and $8.7 \mu \mathrm{g} / \mathrm{ml})$. The highest dose $(870 \mu \mathrm{g} / \mathrm{ml})$ showed a complete spermicidal effect evidenced after $24 \mathrm{~h}$ of storage. This concentration caused alterations probably similar to those described 
in bacteria [50-52]. The mechanism described in bacteria was the ability of the essential oil to disrupt and penetrate the lipid structure of the cell wall leading to the destruction of the membranes [41,42]. Chaftar et al. [53] reported that $R$. officinalis essential oil was active against several strains of Legionella pneumophila with a concentration of $<0.55 \mathrm{mg} / \mathrm{mL}$. As well, Outaleb et al. [54] indicated that rosemary essential oil exhibited appreciate antibacterial activities with concentrations ranging only from 4 to $20 \mu \mathrm{g} / \mathrm{ml}$. Similarly, it is reported that spermicidal activity in numerous animal species is associated with considerable damages on different spermatozoa structures including cell membranes and acrosome integrity $[8-12,31,55]$.

According to the results of this study, the use of small concentrations in vitro might be beneficial to rooster spermatozoa under $4^{\circ} \mathrm{C}$ conditions. In fact, total and progressive motility and kinematics parameters were significantly preserved in 87 and $8.7 \mu \mathrm{g} / \mathrm{ml}$ treatments. After $24 \mathrm{~h}$ of storage, the percentage of progressive gamete was 43.25 and 63.08 at 87 and $8.7 \mu \mathrm{g} /$ $\mathrm{ml}$ treatments, respectively, compared to $26.86 \pm 2.36 \%$ of the control group. Elmi et al. [31] reported that the total and progressive motility was significantly altered from the concentration of $0.8 \mathrm{mg} / \mathrm{ml}$ of $R$. officinalis essential oil in swine spermatozoa. This concentration was almost identical to the spermicidal concentration used in our experiment $(870 \mu \mathrm{g} / \mathrm{ml})$. At $0.2 \mathrm{mg} / \mathrm{ml}$, the authors observed motility values similar to those of the control group. Conversely, when used as supplementation diet, $R$. officinalis essential oil enhanced spermatogenesis and limited lipid peroxidation in quail testicular tissue [55].

Several active molecules such as 1,8-cineole, camphor, $\beta$-thujene, chrysanthenone, $\beta$-cubebene, and camphene, known for their antioxidant activity, were identified in the phytochemical analysis (Table-1). These compounds are probably involved in the observed protective effects. These findings are in accordance with previous reports using rosemary aqueous extract (polyphenols rich fraction) in boar $[28,56]$ and buck [57]. The beneficial effects of $R$. officinalis essential oil may be related to the antioxidant activity limiting lipid peroxidation and membrane damages during the chilling storage.

\section{Conclusion}

The present work reported the usefulness of a low concentration of $R$. officinalis $(8.7 \mu \mathrm{g} / \mathrm{ml})$ in the preservation of rooster semen at $4{ }^{\circ} \mathrm{C}$ for a period long enough to manage successfully AI practice. However, further studies are needed to understand the mechanisms of action and the real impact on fertility outputs.

\section{Authors' Contributions}

MI and LT have conceived and designed the study. LT and BA conducted the study in the laboratory. NM analyzed the data and performed statistical analysis. LT and YB drafted and revised the manuscript under the guidance of MI. All authors read and approved the final manuscript.

\section{Acknowledgments}

The authors would like to express their deepest gratitude to the Faculty of Nature and Life Sciences, University of Bejaia, Algeria, for their technical support. All the authors express their sincere thanks to the staff of the Associated Laboratory in Marine and Aquaculture Ecosystems, Faculty of Nature and Life Sciences, University of Bejaia, for providing all necessary facilities to execute the research work. The authors would like to express their deepest gratitude to the Faculty of Agronomy of Setif, Algeria, for their technical support. This study was supported by internal funding.

\section{Competing Interests} interests

The authors declare that they have no competing

\section{References}

1. Cross, D.E., McDevitt, R.M., Hillman, K. and Acamovic, T. (2007) The effect of herbs and their associated essential oils on performance, dietary digestibility and gut microflora in chickens from 7 to 28 days of age. Br. Poult. Sci., 48: 496-506.

2. Radwan, N.L., Hassan, R.A., Qota, E.M. and Fayek, H.M. (2008) Effect of natural antioxidant on oxidative stability of eggs and productive and reproductive performance of laying hens. Int. J. Poult. Sci., 7: 134-150.

3. Mangiagalli, M.G., Martino, P.A., Smajlovic, T., Cavalchini, L.G. and Marelli, S.P. (2010) Effect of lycopene on semen quality, fertility and native immunity of broiler breeders. Br. Poult. Sci., 51: 152-157.

4. Liu, Q., Duan, R.J., Zhou, Y.F., Wei, H.K., Peng, J. and Li, J.L. (2017) Supplementing oregano essential oil to boar diet with strengthened fish oil: Effects on semen antioxidant status and semen quality parameters. Andrologia, 22: $1-8$.

5. Sebai, H., Selmi, S., Rtibi, K., Gharbi, N. and Sakly, M. (2015) Protective effect of Lavandula stoechas and Rosmarinus officinalis essential oils against reproductive damage and oxidative stress in alloxan-induced diabetic rats. J. Med. Food., 18: 241-249.

6. Ben Slima, A., Ali, M.B., Barkallah, M., Traore, A.I., Boudawara, T., Allouche, N. and Gdoura, R. (2013) Antioxidant properties of Pelargonium graveolens l'Her essential oil on the reproductive damage induced by deltamethrin in mice as compared to alpha-tocopherol. Lipids Health Dis., 12: 30.

7. Köse, E., Sarsilmaz, M., Meydan, S., Sönmez, M., Kuş, I. and Kavakli, A. (2011) The effect of lavender oil on serum testosterone levels and epididymal sperm characteristics of formaldehyde-treated male rats. Eur. Rev. Med. Pharmacol. Sci., 15: 538-542.

8. Chikhoune, A., Stouvenel, L., Iguer-Ouada, M., Hazzit, M., Schmitt, A., Lorès, P., Wolf, J.P., Aissat, K., Auger, J., Vaiman, D. and Touré, A. (2015) In-vitro effects of Thymus munbyanus essential oil and thymol on human sperm motility and function. Reprod. Biomed. Online, 31: 411-420.

9. Paul, S. and Kang, S.C. (2012) Studies on the viability and membrane integrity of human spermatozoa treated with essential oil of Trachyspermum ammi (L.) Sprague ex turrill fruit. Andrologia, 44: 117-125.

10. Paul, S. and Kang, S.C. (2011) In vitro determination 
of the contraceptive spermicidal activity of essential oil of Trachyspermum ammi (L.) Sprague ex Turrill fruits. N. Biotechnol., 28: 684-690.

11. Riar, S.S., Devakumar, C., Ilavazhagan, G., Bardhan, J., Kain, A.K., Thomas, P., Singh, R. and Singh, B. (1990) Volatile fraction of neem oil as a spermicide. Contraception, 42: 479-487.

12. Buch, J.G., Dikshit, R.K. and Mansuri, S.M. (1988) Effect of certain volatile oils on ejaculated human spermatozoa. Indian. J. Med. Res., 87: 361-363.

13. Cuvelier, M.E., Richard, H. and Berset, C. (1996) Antioxidative activity and phenolic composition of pilotplant and commercial extracts of sage and rosemary. J. Am. Oil. Chem. Soc., 73: 645-652.

14. Frankel, E.N., Huang, S.W., Aeschbach, R. and Prior, E. (1996) Antioxidant activity of a rosemary extract and its constituents, carnosic acid, carnasol and rosmarinic acid, in bulk oil and oil-in-water emulsion. J. Agric. Food. Chem., 44: 131-135.

15. Richheimer, S.L., Matthew, W.B., Greg, A.K., Michael, C.K. and David, T.B. (1996) Antioxidant activity of lipid-soluble phenolic diterpenes from rosemary. J. Am. Oil Chem. Soc., 73: 507-514.

16. Rašković, A., Milanović, I., Pavlović, N., Ćebović, T., Vukmirović, S. and Mikov, M. (2014) Antioxidant activity of rosemary (Rosmarinus officinalis L.) essential oil and its hepatoprotective potential. BMC Complement. Altern. Med., 14: 225.

17. Borghei-Rad, S.M., Zeinoaldini, S., Zhandi, M., Moravej, H., and Ansari, M. (2017) Feeding rosemary leaves powder ameliorates rooster age-related subfertility. Theriogenology, 101: 35-43.

18. Surai, P., Cerolini, S., Wisharta, G.J., Speake, B.K., Noble, R.C. and Sparks, N.H.C. (1998) Lipid and antioxidant composition of chicken semen and its susceptibility to peroxidation. Avian. Poult. Biol. Rev., 9(1): 11-23.

19. Breque, C., Surai, P.F. and Brillard, J.P. (2003) Roles of antioxidants on prolonged storage of avian spermatozoa in vivo and in vitro. Mol. Reprod. Dev., 66: 314-323.

20. Surai, P. and Fisinin, V.I. (2014) Selenium in poultry breeder nutrition: An update. Anim. Feed. Sci. Technol., 191: 1-15.

21. Surai, P. (2016) Antioxidant systems in poultry biology: Superoxide dismutase. Anim. Nutr., 1: 1-17.

22. Blesbois, E. and Brillard, J.P. (2007), Specific Features of in vivo and in vitro sperm storage in birds. Animal, 1: $1472-1481$

23. Cerolini, S., Kelso, K.A., Noble, R.C., Speake, B.K., Pizzi, F. and Cavalchini, L.G. (1997) Relationship between spermatozoan lipid composition and fertility during aging of chickens. Biol. Reprod., 57: 976-980.

24. Douard, V., Hermier, D., Magisteini, M., Labbé, C. and Blesbois, E. (2004) Impact of changes in composition of storage medium on lipid content and quality of turkey spermatozoa. Theriogenology, 61: 1-13.

25. Cerolini, A., Zaniboni, S., Maldjian, A. and Gliozzi, T. (2006) Effect of docosahexaenoic acid and a-tocopherol enrichment in chicken sperm on semen quality, sperm lipid composition and susceptibility to peroxidation. Theriogenology, 66: 877-886.

26. Benhenia, K., Lamara, A., Fatmi, S. and Iguer-Ouad, M. (2016) Effect of cyclodextrins, cholesterol and vitamin e and their complexation on cryopreserved epididymal ram semen. Small. Rum. Res., 141: 29-35.

27. Nabi, B., Fatmi, S., Zerrouki-Daoudi, N. and Iguerouada, M. (2017) Interest of Vitamin E and cholesterol preloaded in cyclodextrins on motility of cryopreserved rabbit semen. Revue. Méd. Vét., 168: 87-92.

28. Malo, C., Gil, L., Gonzalez, N., Martinez, F., Cano, R., De Blas, I. and Espinosa, E. (2010) Anti-oxidant supplementation improves boar sperm characteristics and fertility after cryopreservation: Comparison between cysteine and rosemary (Rosmarinus officinalis). Cryobiology, 61: 142-147.
29. González, N., Gil, L., Martinez, F., Malo, C., Cano, R., Mur, P. and Espinosa, E. (2010) Effect of natural antioxidant rosemary in canine soya freezing extender. Reprod. Domest. Anim., 45: 88.

30. Gil, L., Mascaró, F., Mur, P., Gale, I., Silva, A., González, N., Malo, C. and Cano, R. (2010) Freezing ram semen: The effect of combination of soya and rosemary essences as a freezing extender on post-thaw sperm motility. Reprod. Domest. Anim., 45: 91.

31. Elmi, A., ventrella, D., Barone, F., Filippini, G., Benvenuti, S., Pisi, A., Scozzoli, M. and Bacci, M.L. (2017) Thymbra capitata (L.) Cav. and Rosmarinus officinalis (L.) essential oils: In vitro effects and toxicity on swine spermatozoa. Molecules, 22: 2162.

32. Burros, W.H. and Quinn, J.P. (1937) The collection of spermatozoa from the domestic fowl and turkey. Poult. Sci., 16: 19-24.

33. Bozin, B., Mimica-Dukic, N., Samojlik, I. and Jovin, E. (2007) Antimicrobial and antioxidant properties of rosemary and sage (Rosmarinus officinalis L. and Salvia officinalis L., Lamiaceae) essential oils. J. Agric. Food. Chem., 55: 7879-7885.

34. Slameňová, D.H., Horváthová, E., Kováčiková, Z., Kozics, K. and Hunáková, L. (2011) Essential rosemary oil protects testicular cells against DNA-damaging effects of $\mathrm{H} 2 \mathrm{O} 2$ and DMNQ. Food. Chem., 129: 64-70.

35. Luis, J.C., Perez, R.M. and Gonzalez, F.V. (2007) UV-B radiation effects on foliar concentrations of rosmarinic and carnosic acids in rosemary plants. Food. Chem., 101: 1211-1215.

36. Laura, P.F., Garon, M.T. and Vicente, M. (2010) Relationship between the antioxidant capacity and effect of rosemary (Rosmarinus officinalis L.) polyphenols on membrane phospholipid order. J. Agric. Food. Chem., 58: 161-171.

37. Makhloufi, A., Moussaoui, A., Makhloufi L., Benlarbi, Z., Hibi, Ben Nabri, S., Mellouki, S. and Rahal, S. (2011) Microbiological and physicochemical quality of four cultivars of dates in the region of Bechar, South-West of Algeriaoptimization of conservation by Rosmarinus officinalis L. essential oil. Acta. Hortic., 994: 247-255.

38. Djeddi, S., Bouchenah, N., Settar, I. and Skaltsa, H.D. (2007) Composition and antimicrobial activity of the essential oil of Rosmarinus officinalis from Algeria. Chem. Nat. Compd., 43: 487-488.

39. Bajpai, V.K., Baek, K.H. and Kang, S.C. (2013) Control of Salmonella in foods by using essential oils: A review. Food Res. Int., 45: 722-734.

40. Zaouali, Y., Bouzaine, T. and Boussaid, M. (2010) Essential oils composition in two Rosmarinus officinalis L. varieties and incidence of antimicrobial and antioxidant activities. Food Chem. Toxicol., 48: 3144-3152.

41. Boutabia, L., Telailia, S., Bouguetof, I., Guenadil, F. and Chefrour, A. (2016) Composition chimique et activité antibactérienne des huiles essentielles de Rosmarinus officinalis L. de la région de Hammamet (Tébessa-Algérie). Bull. Soc. R. Sci. Liège., 85: 174-189.

42. Burt, S. (2004) Essential oils: Their antibacterial properties and potential applications in foods-a review. Int. J. Food. Micobiol., 94: 223-253.

43. Faid, M., Bakhy, K., Anshad, M. and Tantaoui-Elaraki, A. (1995) Almond paste: Physiochemical and microbial characterizations and preservation with sorbic acid and Cinnamon. J. Food Prod., 58: 547-550.

44. Kadri, A., Zarai, Z., Ben Chobba, I., Bekir, A., Gharsallah, N., Damak, M. and Gdoura, R. (2011) Chemical constituents and antioxidant properties of Rosmarinus officinalis L. essential oil cultivated from South-Western Tunisia. J. Med. Plants Res., 5: 5999-6004.

45. Zermane, A., Larkeche, O., Meniai, A.H., Crampon, C. and Badens, E. (2016) Optimization of Algerian rosemary essential oil extraction yield by supercritical $\mathrm{CO}_{2}$ using response surface methodology. C. R. Chim., Elsevier 
Masson, 19: 538-543.

46. Smeti, S., Atti, N., Mahouachi, M. and Munoz, F. (2013) Use of dietary rosemary (Rosmarinus officinalis L.) essential oils to increase the shelf life of Barbarine light lamb meat. Small. Rumin. Res., 113: 340-345.

47. Zaouali, Y., Messaoud, C., Ben Salah, A. and Boussaid, M. (2005) Oil composition variability among populations in relationship with their ecological areas in Tunisian Rosmarinus officinalis L. Flavor. Fragr. J., 20: 512-520.

48. Ojeda-Sana, A.M., van Baren, C.M., Elechosa, M.A., Juarez, M.A. and Moreno, S. (2013) New insights into antibacterial and antioxidant activities of rosemary essential oils and their main components. Food Control, 31: 189-195.

49. Gharib, F., Ghazi, S., Aly, H., El-araby, M. and Moustafa, S. (2016) Effect of soil type and water content on rosemary growth and essential oil yield. Int. J. Sci. Eng. Res., 7: 183-189.

50. Moreno, S., Scheyer, T., Romano, C.S. and Vojnov, A.A. (2006) Antioxidant and antimicrobial activities of rosemary extracts linked to their polyphenol composition. Free. Radic. Res., 40: 223-231.

51. Jordán, M.J., Lax, V., Rota, M.C., Lorán, S. and Sotomayor, J.A. (2013) Effect of the phenological stage on the chemical composition, and antimicrobial and antioxidant properties of Rosmarinus officinalis L. essential oil and its polyphenolic extract. Ind. Crops Prod., 48: 144-152.

52. Satyal, P., Jones, T.H., Lopez, E.M., McFeeters R.L.,
Awadh, A.N.A., Mansi, I., Al-Kaf, A.G. and Setzer, W.N. (2017) Chemotypic characterization and biological activity of Rosmarinus officinalis. Foods, 6: 20.

53. Chaftar, N., Girardot, M., Quellard, N., Labanowski, J., Ghrairi, T., Hani, K., Frère, J. and Imbert, C. (2015) Activity of six essential oils extracted from Tunisian plants against Legionella pneumophila. Chem. Biodivers, 12: 1565-1574.

54. Outaleb, T., Hazzit, M., Ferhat, Z., Baaliouamer, A., Yekkour, A., Zitouni, A. and Sabaou, N. (2015) Composition, antioxidant and antimicrobial activities of Algerian Rosmarinus officinalis L. extracts. J. Essent. Oil. Bear. Pl, 18: 654-665.

55. Türk, G., Çeribaşı, A.O., Şimşek, Ü.G., Çeribaşı, S., Güvenç, M., Özer Kaya, Ş., Çiftçi, M., Sönmez, M., Yüce, A., Bayrakdar, A., Yaman, M. and Tonbak, F. (2016) Dietary rosemary oil alleviates heat stress-induced structural and functional damage through lipid peroxidation in the testes of growing Japanese quail. Anim. Reprod. Sci., 164: 133-143.

56. Malo, C., Gil, L., Cano, R., Martínez, F. and Galé, I. (2011) Antioxidant effect of rosemary (Rosmarinus officinalis) on boar epididymal spermatozoa during cryopreservation. Theriogenology, 75: 1735-1741.

57. Zanganeh, Z., Zhandi, M., Zare-Shahneh, A., Abozar, N., Nabi, M.M. and Sangcheshmeh, M. (2013) Does rosemary aqueous extract improve buck semen cryopreservation? Small Rumin. Res., 114: 120-125. 